\begin{tabular}{l} 
RCCS \\
\hline Annual Review
\end{tabular}

\section{RCCS Annual Review}

A selection from the Portuguese journal Revista Crítica de Ciências Sociais

\#0 | 2009

Issue no. 0

\title{
From Identitary Construction to a Web of Differences: A Glance at Portuguese-language Literatures
}

\author{
Laura Cavalcante Padilha
}

Translator: Monica Varese

\section{(2) OpenEdition}

\section{Journals}

Electronic version

URL: http://journals.openedition.org/rccsar/117

DOI: $10.4000 /$ rccsar. 117

ISSN: 1647-3175

Publisher

Centro de Estudos Sociais da Universidade de Coimbra

\section{ELECTRONIC REFERENCE}

Laura Cavalcante Padilha, « From Identitary Construction to a Web of Differences: A Glance at Portuguese-language Literatures », RCCS Annual Review [Online], \#0 | 2009, Online since 01 September 2009, connection on 22 April 2019. URL : http:// journals.openedition.org/rccsar/117 ; DOI : 10.4000/rccsar.117 


\title{
Laura Cavalcante Padilha
}

Fluminense Federal University, Brazil

\section{From Identitary Construction to a Web of Differences: A Glance at Portuguese-language Literatures ${ }^{*}$}

\begin{abstract}
Based on an overview of Afro-Luso-Brazilian literary productions, this article discusses the issue of the Portuguese language, its expansion and the web of differences it harbours. To achieve this wider goal, the article addresses two symbolic constructs which ultimately supplement each other when more ample linguistic constructs are taken into consideration. Firstly, the spotlight is cast on the issue of Lusism, read as an identitary construction which, within the Portuguese artistic-verbal space of creation, initially cast itself euphorically and then was problematised to such an extent that it often became dysphoric. This is followed by a discussion of Lusophony, read, with Eduardo Lourenço, as a "mythology" which takes on meaning only if account is taken of existing identifications among the various intercontinental speakers of the language, on the one hand, and on the other, of the diversities which profoundly differentiate them.
\end{abstract}

Keywords: Portuguese-language literatures; Portuguese language; Lusism; Lusophony; identity construction.

\section{Brief initial outlines}

The act of pondering the issue of the Portuguese identitary cartography implies considering a trajectory which ranges from its imaginary construction to its expansion beyond European geographical and cultural boundaries and buttresses. Portuguese-language literary production captures this trajectory, from the point of view of both - it is fair to say - its "luminous" affirmation and its problematic aspects, as well as in its collision with the ethno-cultural differences of the non-European peoples whose symbolic matrices coloniality (Mignolo, 2003) sought to elide. The Portuguese language was - and is - the cultural element which was made into one of the main foundations of the identitary constructions in the European space as well as of the sedimentation of what we can consider as being the web of differences which was and is woven in the colonised countries where it became either the national tongue, or the official language.

Following this imaginary trajectory, built up by the ethical, historical and cultural body of Lusitanity, two symbolic constructs are arrived at: Lusism, interpreted as something which spills over from the linguistic domain to become a way of affirming itself in the European

\footnotetext{
* Article published in RCCS 73 (December 2005).
} 
space, and Lusophony, which emerged in the wake of the expansion of the language and culture beyond Europe, when both were disseminated among peoples of different origins in America, Africa and even parts of Asia and Oceania. In this process of expansion, the Portuguese language gained other subjects who "speak it, speaking of themselves in it," as Eduardo Lourenço puts it (2001: 123), and for this very reason it became one of the main threads in the weaving of the fabric of the new ethno-cultural web which thus emerged.

The sea, by then made Portuguese, as much by the concrete historical given as by the imaginative route represented at first by the aesthetic efficacy of Camões's epic, becomes the main route of this identitary trajectory in the process of expanding, by which, more so than the language, an entire imaginary was disseminated. Lusism and Lusophony intersect, the latter being the destination of the former.

In turn, the literatures produced in Portuguese ultimately become a tool of cultural dissemination. It is through them that, in the case of European literature, the diverse euphoric and dysphoric moments of Lusism are played out; and the other literatures also show the serious clashes engaged in by the different cultures which were subdued in the process of seizing unknown peoples and lands, always following the dictates of the political-economic project of overseas expansion. Lusism and Lusophony ultimately become important focal points for researchers who choose such literatures as their research areas. The study of these literatures is greatly enhanced by considering Lusism and Lusophony in relation to each other, showing the clashes that arose from the construction of the Portuguese-language cultural space. This applies as much to the literature produced in Europe, it too brimming with perplexities, confrontations and erasures, as it does to the artistic manifestations of the dominated peoples, who from the start were excluded from the literate universe.

Such issues gain even more theoretical-critical weight at the present time when literary and cultural studies find themselves in an in-between space created by the porousness of their previously significantly rigid frontiers. Now new negotiations emerge with a bearing on meaning in the area of contemporary literary studies, as a predictable outcome of their dialogue with cultural studies. This new methodological stance seeks to contribute to a break with the politics of silence which always descended on that which was deemed as being "non-canonical," and for that reason was removed to the margins of what hegemonic literary culture hallowed and still hallows. Productions in the Portuguese language, 
especially those of non-European origin, were summarily excluded from the "Western canon," as has already been quite widely discussed and exposed by the "resentful ones," in Harold Bloom's classification, the latter, incidentally, being one of the authors most closely committed to setting up that very same canon (1995).

A prior statement of clarification is here in order as to my own locus of enunciation, Brazil, the place which underpins my personal and academic discourse and, to some extent, conditions my reading - allowance will be made, I hope, for this personal touch - of the issues raised from this point on. In addition, my research interest lies in African literatures in the Portuguese language, with special emphasis on those produced in Angola and Mozambique. Such a network of belonging and choices causes a kind of crossroads to emerge, moulding types of knowledge and issues of a cultural nature among which I move and which lead me to tread various and supplementary paths. Although diverse, these have a point of convergence: the Portuguese language, a frame which embroiders and reinforces my own subjective, historical and political experience and, in a special way, my imaginary readers - the latter indeed being the trigger for the reflections which follow.

The goal of this article is clear: to bring to the surface the Lusism movement, such as the Portuguese literary series mapped it, and to problematise the issue, for some equanimous, of Lusophony. This construct is sustained by what Lourenço aptly terms "Lusophone mythology" (2001: 178), an idea that will provide the necessary foundations for the reflections contained in this article. The starting point, or the first movement of the text, as already stated, will be an analytical reading of Lusism, as it plays itself out in the Portuguese fictional webs. I will seek to apprehend in them a type of historical, symbolic and cultural concatenation, ranging from the creation and reinforcement of the concept, to some degree euphoric, to the later problematisation which exists to this day. I will then consider the issue of Lusophony, understood in the power of its difference, more than in any presumption of unity and/or hegemony.

\section{Lusism: Construction, reinforcement and reconfigurations}

In the linguistic field, and referring readers to Antenor Nascentes, the word Lusism means "a word, expression, construction, peculiar to the Portuguese language spoken in Portugal" (1972, 4: 1015-b). This meaning, with merely formal variants, appears also, for example, in 
the Brazilian edition of Caldas Aulete's dictionary, coordinated by Nascentes himself (1958), reappearing in Antônio Houaiss's dictionary (2001) and again in that of Aurélio Buarque de Holanda Ferreira (1988 and 1999). Alongside this initial meaning, a further definition is recorded whereby the word is presented as a synonym of Lusitanity, that is, according to Antônio Houaiss, "the peculiar, individualising character or quality of what or who is Portuguese" (2001: 1792-c). Thus, Lusism is seen as an identitary construction, and it is on this sense of the word that this article will centre.

As is well known, each and every identity - even if we take into account the fact that there is no assumption of immutability, permanence or essence underlying the meaning of the concept (Hall, 2003: 10-3) - presupposes a feeling of belonging, almost always arising when there is a face-to-face encounter, or at least a symbolic negotiation between an "I" and an Other, or, to use Todorov's term, between "us and them" (Todorov, 1989). Thus, to build itself as difference in the Iberian space, Portugal initially confronted the Other, the Castilian, since its creation by Afonso Henriques, of the first Alphonsine dynasty. To set himself up as master of the land already extended by his father, Henry of Bourgogne, the son fought against his mother and stepfather for possession of the territory. This matricidal confrontation birthed what we can call, with Lourenço (1988), the traumatic origin of the Portuguese State, a trauma which would, from its inception, mark the "imagined community" (Anderson 1989) that we call Portugal.

In the texts of Fernão Lopes, the first Portuguese medieval chronicler, we find the first foundations for the building up of Lusism, just as the $16^{\text {th }}$ century, with Camões's epic, hallowed it. We need but read, for example, the episode regarding the so-called "Siege of Lisbon" in Crónica de Dom João [Chronicle of King John] (1st ed.: 1644), to realise, especially because of the force attributed to the besieged people in the city, the nature of the clash between the Portuguese and the Castilians. For his part, the second chronicler, Gomes Eanes de Zurara, foregrounds, in his Crónica da Tomada de Ceuta [The Chronicle of the Capture of Ceuta] (1st ed.: 1644), the spatial situation of Portugal, wedged between Spain and the sea, when he writes: "as for us, on one side the sea encircles us and on the other we have our battlements at the kingdom of Castile" (1992: 52). This territory thus "encircled" with but two frontiers, takes on another historical, symbolic and even geographical dimension, as it expands its European spatiality when it appropriates, by the colonising process, parts of America, Africa, Asia and Oceania. 
The work which captures the moment of expansion and greatness, whereby the then known world gained another configuration, becoming globalised, is beyond doubt Luís Vaz de Camões's The Lusiad (1572). It is no coincidence that his modern epic, written in Portuguese in the $16^{\text {th }}$ century, became the great sustaining block of the Portuguese imaginary, or its great reference, as Lourenço so rightly notes (1988: 151). The moment of unequivocal greatness leaps from history into fiction, as it is woven, as already stated, by the aesthetic efficacy of Camões's words. The future opens up for Portugal, luminously, in the poetic word, on the eve of closing down abruptly upon the death of King Sebastian and the loss of Portuguese political hegemony to Spain (1580-1640).

Thus, the greatness mapped out along the path of fictionality in a sense signals what became of national history itself, as we know. "Every Portuguese road leads to Camões" and to his epic, thinking here with José Saramago (1984: 180-81). The text seems to fit every purpose, and from it, ideologies and counter-ideologies have gathered strength, as well illustrated in the dialogue proposed, again, by Saramago in his play Que farei com este livro? [What Shall I Do with this Book?] (1979). The following dialogue unfolds between Diogo do Couto, Camões and Damião de Góis, emblematic historical subjects, and takes place in the tense moment when the epic poet, in the fictional fabric of the play, struggles to have his book published, finding closed doors where he would wish to find help:

LUIS DE CAMÕES: However, the book will not be different from what it is.

DAMIÃO DE GÓIS: The difference will lie in the eyes that read it. And the part that emerges victorious will see to it that the book is read by the eyes that best suit it.

DIOGO DO COUTO: And the losing side, what will they do?

DAMIÃO DE GÓIS: They will wait for their turn to read and make it be read differently. (Saramago, 1998: 55).

Through this infinite possibility of readings, the European identitary fabric and its textual reinforcement transform Camões's epic into a promise of some measure of future and offer the meaning for each present experienced since then, even when the ideology underpinning the work is impugned. Through it is forged an auratic past, of which the Portuguese national imaginary has always been able to avail itself, disseminating it in one form or another. Thus it is that Lourenço states the work to be "the unanimous reference of what we can call, in all ambiguity, the 'national spirit'” (1988: 151). 
Therefore, Camões's epic text builds up the locus of strength of Lusism, going beyond the constraints of time and space, mainly because the work makes clear a supplementary counterpoint in what concerns the construction of the identitary features. Better put: The Lusiad shows the Portuguese diachronically as a people which, in European terms, confronted its Iberian peninsular Other, the Castilian people, in order properly to outline its profile in difference. This profile has one of its strongest features in the languages spoken on either side of the frontier. At the time of Gama's voyage, turned into synchronic time by the presentification of the narrative - lest we forget that he too is one of the narrators of the Portuguese "past" - other Others appear, outside the peninsular and European space, Others who in the end intensify even further the features of the Lusitanian identitary cartography. The south, where Portugal is located and which defines it in the European space, seeks spaces in the southernmost South, where the "noble barons" will experience, to quote Fernando Gil, "the surprise continually aroused by that which is absolutely new, as terrifying as it is dazzling" (1998: 37, emphasis in original).

Throughout Camões's poem, there is thus a parade of several Others - Moors, Africans, Indians - who reinforce Lusitanian identity by the face-to-face encounter with different historical-cultural subjects who confront them as difference. The portals of the colonising process open up, and such Others are compelled to exchange their identitary masks in the name of Faith and Empire. This process brings about the intersection of "radically different and even incompatible socio-cultural universes," as António Cornejo Polar notes (2000: 77), when directing the spotlight on the colonising process of Hispanic America. In the Portuguese case, this was the moment when Lusophony pounded its first stakes into the cultural ground and began to build its future. For this very reason, Camões's text will be summoned once more in the part that follows.

The locus of greatness became problematised, right from the $17^{\text {th }}$ century, when, following Boaventura de Sousa Santos, Portugal became a "semiperipheral country within the modern capitalist system" (2001: 23). The greatness built up by the history of the 1500 s and amplified by Camões's voice was then plunged into crisis. From then on, it became more and more diminished, taking on, in the $19^{\text {th }}$ century, an undeniably traumatic dimension. This latter century saw the crumbling of the entire euphoric imaginary construction of Portuguese identity. In its historical condition as a European imperial country, Portugal lived, in the 1800s, through a harsh experience of successive losses that led to what Margarida 
Calafate Ribeiro has termed a "hangover brought on by a century of traumas." And she continues:

Weakened, struck at the core of its imperial consciousness, Portugal found itself in its small and marginal European position, lacking a new space that, in its own eyes and in others', might make up for its actual little weight in the "Balance of Europe", on which Garrett had, really and symbolically, weighed Portugal. (Ribeiro, 2004: 55)

Two writers of fiction in particular gave shape to this blank page which resulted from the fading away of what was then already a merely imaginary greatness. They are Almeida Garrett and Eça de Queiroz. Among these writers' works, two stand out as of greater significance to this article's reflections, and they are respectively Viagens na minha terra [Travels in my Homeland] (1846) and A llustre Casa de Ramires [The Illustrious House of Ramires] (1897 and 1900). These put forward a new way of reading Portugal and its identitary cartography, at that historical moment of sheer symbolic and institutional crisis.

Garret's Travels propose the trajectory of the Tagus, in lieu of starting the journey across Camões's sea, in search for an "ever-to-be-found port," as Pessoa's future voice was to proclaim (1974: 79). Readers are invited by the novelist to push onward into the land where they will discover the submerged myths and understand the meaning of the people's strength as a transforming agent of history. To achieve his intention, Garrett takes up anew the perspective of Fernão Lopes, especially in the scene where, almost at the end of the novel, the narrator decides to leave Santarém, the last river port of his journey into the country. In this chapter, and upon viewing the decaying tomb of King Fernando, one of monarchs whom Lopes had hallowed in his chronicle, Garrett analyses the decay of Portugal itself. He asks where the tombs of Camões and Duarte Pacheco might be - the latter incidentally always more forgotten than the former - and proceeds to state:

Another ten years of barons and of nature's way, and infallibly we will lose the very last sigh of the spirit from this agonising body which is Portugal.

I believe this with the utmost conviction.

But I have better hopes, nonetheless, because the people, the people is sound [...].

We who are the base prose of the nation, we do not understand the poetry of the people. (Garrett, 1946: 375)

It is interesting to see that the word breathed in Travels continues to be that of Camões, just as the inside out motor of greatness is sought in the fabric of the $16^{\text {th }}$ century epic in a game of attraction/revulsion, as evinced in Chapter VI. In this, the narrator affirms his 
continued belief in Camões, that he feels "while reading The Lusiad" an "intimate feeling of the beautiful" (emphasis in original), although he cannot enjoy "pleasures in the present, in which love of the fatherland" is perhaps no more than a "phantasmagoria," compromising the "hopes for the future" (Garrett, 1946: 47-8).

The quest for past greatness, moving Garrett's journey more along the path of the medieval chronicles than along that of the Renaissance epic, is announced in the first chapter in a spirit which is positive, joyful, and, to some extent, euphoric. This fades away at the end, but the author salvages the beauty of the land and of its submerged myths and stories, despite the disheartened final reckoning. At the beginning, with his usual irony, the narrator presents his "proposition," telling of the ambition of his "pen" which "wants a broader subject" and announcing his "travels," situated in the present and not in past memories, although he extols the glorious memory the land holds. He goes on to say: "I am going to Santarém, no more and no less." He then signals his intent to "chronicle" everything he sees and hears in this Ribatejan town which he considers "the most historical and monumental of our towns" (ibid.: 3-4). The result of this journey towards historical and identitary recognition is, when all is said and done, crossly melancholic, as we know. It closes in the shape of a ruin, metaphorised by that of the town of Santarém itself, although, as already stated, the people is extolled:

Decidedly I am leaving, I cannot be here, I do not want to see this. It is not horror that strikes me, but nausea, disgust, and anger.

Cursed be the hands that defiled you, Santarém... that dishonoured you, Portugal... that debased and degraded you, you nation which has lost all, even the pillars of your history!...

Woe, woe, Portugal! (Garrett, 1946: 374)

For his part, fifty years later, Eça de Queiroz too decided to stage journeys, in The Illustrious House of Ramires. The first of these, imaginary with regard to the story within which it is embedded, appears in the form of a rewriting of the past by the main character, Gonçalo Mendes Ramires. This rewriting becomes the novel A torre de Dom Ramires [The Tower of Dom Ramires], originally a romantic poem authored by one of Gonçalo's uncles. It duplicates, back to front, the present time of the narrative, supplementing it.

In the character's work the past returns, phantasmagorically wrapped in and wrapping itself around the present time of the narrative. Thus, even though taking the personalised shape of a family history, the latter is necessary to "resurrect these men [...] the brave soul, 
the sublime will which nothing bends" - as José Castanheira, friend and publisher of the novel, says when he urges Gonçalo to write about his ancestors. Camões again appears, and Castanheira's desire is, through fiction, to take up anew the lost greatness, shaking off " $[\mathrm{b}] \mathrm{y}$ the renewed awareness of our having been so great, [...] our tepid consent to remain small!" (1947a:19). The success of the novel when it was published shows that the wish to "startle Portugal" was fulfilled (ibid.: 18), nourishing the present with past greatness, even though its author, Gonçalo Ramires, repudiates that past at the end of his work, when, moved by the cruel and inhumane death of Lopo de Baião, the Bastard, he is led to say, "the martyrdom of the Bastard had left him with an aversion for that remote Alphonsine world, so bestial, so inhumane!" (ibid.: 377).

On the other hand, there is a second journey in The Illustrious House, on the diegetic plane, that is, that of Gonçalo to Africa on the passenger ship Portugal, another of the author's corrosive ironies. From thence Gonçalo returns four years later, by this time transformed by the colonial African adventure of 1819. Through this adventure, and in the spirit of what Rider Haggard had put forward in King Solomon's Mines - a novel which was translated or merely revised by Eça (we do not know) and published in Portuguese in 1891 Gonçalo is enriched, returning, as his cousin Maria Mendonça's letter advises, "On great form! More handsome even and above all more of a man. Africa has not even lightly tinged his face. He is as fair-skinned as ever" (ibid.: 409). The greatest nightmare of the European white West had thus been averted: during his Mozambican sojourn, Gonçalo's skin had not been darkened, nor had he "gone native." At this moment, Eça's text shows the power of the intrinsic racism that Kwame Anthony Appiah writes about (1997), whereby the historical Western white subject considers his race to be hegemonic, to the detriment of other races, always seen as inferior and thus a fair target for subjugation, indeed as they are presented in The Lusiad.

Seen through our own eyes today, we can problematise the sudden enrichment of Gonçalo, who, with the money picked from the African shilling and pence tree, transforms his metropolitan territoriality both physically and economically. Thus is shown, in the play of the imaginary, that Africa was still worthwhile and that it had been possible to fulfill the character's dream of "a field in Africa, under murmuring coconut trees, enveloped by the peppery scent of radiant flowers, which thrust upward from among boulders of gold" (ibid.: 59). In this context, it is worth turning to an essay by the Brazilian historian Alberto Costa e 
Silva, in which he challenges the notion that the character could possibly have gained riches by legitimate means in such a short period of time: "And if the nobleman of the Tower got rich in such a short time, it can only have been through much luck, abuse or cunning, or because he oppressed the villages that existed in his domain and wrung from them everything they had to give and yet some" (Silva, 2000: 13). If we bear in mind that Gonçalo is identified with Portugal by Gouveia, because of his "entirety [...], his weakness, sweetness of disposition, kindliness" (Queiroz, 1947a: 418), and especially because of his physical and symbolic re-energising, his enrichment may be read as the possibility of renewal of the European colonial power. António Candido sees in Gonçalo's revitalization “the re-energising of the national consciousness which inspired so many Portuguese intellectuals at the end of the $19^{\text {th }}$ century, as epitomized in the patriotic biographies of Oliveira Martins in his later phase" (2000: 21). With its own corrosive irony and its play of ambiguities (as I see it), the text lets the matter remain unresolved, as a merely possible interpretation. In this returning, I perceive, purely and simply, yet another barb of Queirozian irony, a tangible result of his own disenchantment.

In the $20^{\text {th }}$ century, Pessoa's Mensagem [Message], taking the path of messianism, sets out to conjure up anew the greatness of the past, giving more weight to the power of symbolic, rather than physical, territoriality. For this reason, after singing the building of his "Portuguese sea," he ends his poem with the line "The hour is come!," followed by the Latin expression "Valete, Fratres" (1974: 89).

After the Revolution of the $25^{\text {th }}$ of April of 1974, and with the independence of the African colonies - to take a necessary leap - the process of Portuguese autognosis finds its deepest thrust especially in fiction. Among the voices which show the shattering of what might be called euphoric Lusism, it is difficult to choose those which best represent the endeavour to establish new historical-cultural negotiations which might still sustain the quest for a present time by national subjects who were divided and plunged into an identitary crisis. While Gonçalo Ramires leaves for Africa on the "passenger ship Portugal," it is not by accident that the narrator of Helder Macedo's Partes de África (1991) returns from it at the age of 12 , reaching Lisbon on another vessel called, in contradistinction to the former, Colonial. On this return voyage, the narrating subject tells us the ship put in at "Cape Town, Moçamedes, Lobito, Luanda, São Tomé, Madeira." As a result of moving from one 
territory to the other, he later shows he had "an undefined feeling of injustice which [he] confusedly feared might correspond to a new way of being in the world" (1991: 13).

This "new way of being in the world" is one of the hallmarks of the subjects who can be seen in the works of José Saramago, of Helder Macedo himself, of Lobo Antunes, of João de Melo and so many others who, like the latter, set out to conduct some type or other of Autópsia de um mar em ruínas (1984) [Autopsy of a Sea in Ruins]. To materialise this intention, at times, as with Garrett, the direction chosen is inland, as is the case of Saramago's work, be it in Levantado do Chão [Risen from the Ground] (1979), or Memorial do Convento [Memoirs of the Convent] (1982); at others, writers point to post-colonial travel and to exile as the only possible response to the shattering of a subject who no longer identifies with the sense of the hegemony of Empire. Such is the case of Partes de África and even of Pedro e Paula, also by Helder Macedo (1998), besides the novel which I will take as a possible paradigm for the problematisation of Lusism, in the period following the overthrow of Salazar's fascist regime and the loss of the colonial empire. The novel concerned is Lobo Antunes's O Esplendor de Portugal [The Splendour of Portugal] (1997), a title which clearly echoes the national anthem, whose lyrics were written by Henrique Lopes de Mendonça. Non-coincidentally, part of the anthem is used as an epigraph, which in itself configures a more than symbolic and symptomatic rhetorical procedure. I quote:

Heroes of the sea, noble people,

Brave and immortal nation,

Lift up today anew

The splendour of Portugal. (Antunes, 1999: 5)

The novel smashes to pulp in every sense the motif proposed, staging, rather than the splendour, the absolute decadence of the overseas imperial dream. The writer achieves this, at times by making the narrative action unfold in the former colony, Angola, by now transformed into an independent nation, at other times by changing the space of action to Portugal, to which the last three descendants of a white Angolan colonial family repair in the post-independence period, at the outbreak of the civil war in this African nation. Loneliness, illness, madness, exile, hallucinated reality characterize both spaces, turning the "splendour" into a sea of ruins whose "autopsy" is carried out in an angst-ridden and surprising fashion.

Forsaking any form of linearity, this text displays the fragmentation of national history projected metonymically onto that of subjects without a family locus - by structuring the 
narrative from dated fragments which are organised into three parts, according to the viewpoint of this colonial family's three siblings, exiled in a land which is no longer theirs, Portugal, and with which they no longer identify - Carlos (the father's bastard son and a mestizo); Rui (the schizophrenic son of an adulterous affair of his mother's); and Clarisse (the couple's daughter born in wedlock). Throughout the three parts, the mother, Izilda, speaks from Angola, more precisely from the interior of this country. Her words are triggered by the play of memory which envelops the different periods of the character's life since her rural childhood, always in the Cassanje region.

In contrast to the lyrics of the national anthem, Izilda, a white woman whose forebears were Portuguese colonists, is not a "mighty dawn," but a being immersed in a dark night with no exit. In addition, her "mother's kisses" do not protect or sustain her children "against the affronts of fate." Quite the contrary. Through the imagery associated with this character, the anthem loses its patriotic sense and turns inside out. Furthermore, as Izilda does not leave her Angolan territoriality, or her "fatherland," not returning to Portugal, she compels the reader to plunge into an ever-elided locus from the perspective of coloniality, which is sustained from the start by hegemonic Lusism itself. In this cartography, Lusism is thus reconfigured in the shape of loss, as if it were a film negative.

The death of Izilda, gunned down by Angolan government troops - and not by UNITA - at Christmas of 1995, the date of the piecing together of the textual mosaic, shows her place of non-belonging, her exclusion from Angola too, her nowhere place, in sum. On the other hand, the supper which does not take place, during which the siblings were meant to meet in the European metropolis which is Lisbon and in Carlos's belated dream of seeing them again - undoes any chance of renewing ties of affection. Each of the three emerges in their irreversible loneliness, which at the same time negates any chance of rebirth to which the idea of Christmas might point. In Maria Alzira Seixo's felicitous analysis, "It is, in fact, the issue of agency on the post-colonial plane which is here at stake, and which in this work follows upon the confirmation of the strangeness and disruption of identities" (2002: 353).

This "disruption of identities" offers one of the keys to reading The Splendour of Portugal and other contemporary Portuguese fictions in which Lusism is reconfigured and sets forth in search of new meanings, as yet concealed in the margins of a future-to-be. Perhaps Saramago intuited a possible solution in his Jangada de Pedra [Stone Raft] (1986), showing "the peninsula" as "a child who was formed on its travels and now tosses in the sea in order 
to be born, as if it were inside an aquatic uterus" (1986: 139). The new chance for rebirth points here to a reconfiguration of Lusism, sustaining the very idea of Lusophony as a symbolic place to be erected, since the raft drops anchor - in an equally symbolic geographical coordinate - between Africa and America.

\section{Lusophony: Symbolisations and the web of differences}

I have already stated that, just as much as Lusism, Lusophony at first constitutes a linguistic fact. As with the former, it comes to mean, in a more encompassing context, a political gesture which affirms Lusitanian symbolic-cultural strength, as is the case with Francophony, Anglophony, and so on, constructions whose point of departure is signaled by the hegemony of the colonising nations and by the equally hegemonic language spread by the colonising process.

The competent research conducted by Ana Isabel Madeira, within the Prestige network, traces "the trajectory of the emergence of the Lusophony category" (Madeira, 2003: 6). This author begins by showing the late recording of the term in dictionaries, which coincides with the equally late entry of the construct in the area of Portuguese Studies. This situation can also be confirmed by the fact that in Brazil the term only appears in the dictionary edited by Antônio Houaiss. It reads as follows: "1. the sum total of those who speak Portuguese as their native language or otherwise. 1.1. the sum total of countries having Portuguese as their official or dominant language" (2001: 1793-a). Also, in the electronic version of Aurélio's dictionary (1999), the following is recorded: "Adoption of the Portuguese language as a cultural language or lingua franca by non-native speakers; this occurs, for example, in several countries colonised by the Portuguese." This compiler provides a further definition: "A community formed by peoples who ordinarily speak Portuguese."

Having read these definitions, it becomes quite clear that Lusophony is always conceived of in an oppositional way, whereby the Portuguese language manifests itself as "mother-tongue or not," "official or dominant," or further "cultural language or lingua franca." In other words, there is always a difference in the use of the language and in the relation of belonging established by its use. This reinforces, to return to Madeira, "the notion of Lusophony as a unit in the functioning of discourse [...] as a feature in the chain of narratives that articulate the history of the peoples who use the Portuguese language" 
(Madeira, 2003: 13). The "feature" singled out by Madeira becomes blatantly obvious in Houaiss's definition, when the latter spells out such "chain of narratives" in square brackets:

[Besides Portugal, Lusophony includes the countries colonised by Portugal, as follows: Brazil, Mozambique, Angola, Cape Verde, Guinea-Bissau, São Tomé and Príncipe; it further includes the varieties spoken by part of the population of Goa, Damão and Macau, in Asia, and also the variety spoken in Timor, in Oceania] (Houaiss, 2001: 1793-a).

In the context of the reflections I propose here, the space I shall approach will be that of the African countries once colonised by Portugal, whose literature, as already stated, is my main field of research. However, I will also call upon Brazilian literature, for, in the community in which we all, speakers of Portuguese, take up our place, there is a series of identifications that bring us together, side by side with the far-reaching diversities which differentiate us. Since Portuguese literature has already been covered in the previous section on Lusism, I will not discuss it here. However, we cannot ponder Lusophony without going back to The Lusiad, if literature in Portuguese is the goal of the mind's eye.

The nature of the meeting of the Selves, the Portuguese, and the Others, the Africans, in the specific case of the $16^{\text {th }}$ century epic, is brought to the fore in several passages. In the play of representation, at times the encounter becomes more palatable, when the possibility of linguistic communication is there, at others it turns into fortified battlements, when the always "alien" "people" does not have a grasp of any recognisable code. There is an issue, raised by the navigators right at the start of the voyage (Canto I, 42), which eventually opens the curtains of the first protocolar scene presenting European subjects and the inhabitants of a small island glimpsed by Gama. I transcribe it (my italics): "What people can these be (they said to themselves) / What customs, what law, what king might they have?" (1972, I, 42: 71). The issue thus posed becomes the motif for later encounters with other identitary formations.

Continuing the previous scene, the Portuguese present themselves thus: "Portuguese are we from the West / We search for the lands of the Orient" (ibid., 50: 17). To this statement the Others thus engaged retort in Arabic, understood by some, as the text clarifies on several occasions:

We are (one from the islands replied)

Strangers in the land, law and nation;

For the natives are those whom

Nature created, lacking law and reason. (ibid., 53, 1 to 4: 75) 
The Black Africans, owners of the island which has already been invaded and which we will later learn is called Mozambique, are excluded from the scene and viewed as being created by nature, "lacking law and reason." On the representational plane, the void of the subject who owns the land is thus established. It is only in Canto $\mathrm{V}$, therefore much later in the text and through Gama's words, that readers are informed of the existence of a prior encounter - the first in the narrative's flashback montage, with the Blacks metonymically represented by the figure of one of them, described as "a strange, black-skinned being" (ibid., V, 27, 6: 296). In the next stanza, this "strange being" is characterised as being "more of a savage than the brutish Polyphemus" (ibid., 28, 4: 296).

At this point in the narrative, the linguistic battlements take shape and the result is incommunicability between the two ethno-cultural groups who, for the first time, come face to face. Gama says: "He neither understands us, nor we him" (ibid., 28, 3: 296). There is thus no dialogue, nor a protocolar introduction, for there is no prior knowledge of the codes of either people, which leads to an absolute impossibility of linguistic intercourse. Inevitably, all this will be followed by the first physical clash, with arrows on the one side and firearms on the other. The cultural worlds are mutually exclusive and confrontational, precisely because of the absence of porous linguistic frontiers where they might intersect. This is, incidentally, the moment when the curtain is raised on the drama of colonisation, coinciding with the moment when, I repeat, Lusophony starts to become future, and the language of the dominator enforces itself as hegemonic, because it is the only one which makes sense in that "alien" world where it puts in, a world characterised by "savagery."

At this stage, there is a need to clarify that we, the former colonised, speak the Portuguese which has reached us as a legacy of the European other, and with the variants resulting from the cultural formation of each of our countries, mapped by geographical lines and boundaries set down by the hegemonic colonial power. It is in this Portuguese language that we tell of ourselves and, in some places, build part of our national identities.

Emphasising the strength of these linguistic diversities that differentiate us, José de Alencar, the Romantic writer who, more than most, sought to construct the pathways of a Brazilian literary nationality inscribed in difference, rhetorically asks, in his preface to the novel Sonhos d'ouro (1872) [Dreams of Gold]: "Can the people who suck the cashew fruit, the mango, the cambuca and the jaboticaba speak a language with the same accent and the same spirit as the people who drain the fig, the pear, the apricot and the loquat?" (1953: 
88). We all know that the verb "to suck" means the same as "to drain," but between the two signifiers and their respective significations there is an Atlantic distance separating the gesture and the "flavour" of the two actions, besides the diversity of the fruit which is "sucked" or "drained."

On the other hand, we must consider that the Portuguese language was harshly imposed by European domination, as can be seen, for example, in the rigid rules of the statute whereby the process of assimilation in Africa was upheld. We should not forget that assimilation was the only way Blacks had of accessing a range of rights enabling them to rise to merely middle-ranking citizenship status. In his penetrating analysis, Alfredo Margarido summarises the meaning of this imposition, when he states that the tool of linguistic domination aimed to

ward off the Other and most especially the groups classified by European proto-anthropology as falling under the category of savages: those without a territory, without a government, without a religion, Africans and Native Americans. Which is not to say that Asians were entirely free from this condemnation. Tell me what language you speak and how you speak it, and I will tell you who you are not - such could be the central aphorism associated with Portuguese linguistic practices. (2000: 66-7)

It is starting from this idea of linguistic dominance, to which the deliberate erasure of autochthonous symbolic representations is linked, at every stage under the dictating force of European representations, that Lusophony must be considered, including it in the context of the "sociology of absences." As formulated by Arriscado Nunes and Boaventura de Sousa Santos, this sociology is to be understood as "a resource [...] capable of identifying the silences and the multiple manifestations of ignorance which define the incompleteness of cultures, of experiences and of knowledges" (2003: 26). It is in this space where silence is erected on that which we do not know and do not even wish to know that Lusophony moves. Precisely because of this, it must be pondered as a political gesture that underpins an entire symbolic construct, through which frequent attempts are made to erase the web of differences which nevertheless insist on projecting themselves onto the meshes, in the event, literary, woven by the fabric of the imaginary of producers from the countries once colonised by Portugal. As Cornejo Polar quite aptly stresses with regard to Latin-American literatures, a formulation easily extendable to African literatures, such productions set themselves up as 
a field unlocked to the unsaveable heterogeneity of plural and dissident voices and letters, to the many stages of a history which is more awe-inspiring and dense than its linear equivalent, to the various, nuanced and confused consciousnesses which cross them and confer on them bewildering consistency. (2000: 84).

Turning once again to the linguistic issue, a basic assumption must be considered when pondering the community of the seven countries where Portuguese appears as a mother-tongue, a cultural, official or dominant language. It is the fact that, in the intercontinental projection of this language, there is a foundational difference between what happens in Brazil and Portugal, on the one hand, and what happens in the historical-social space of the five African nations, on the other. Here, Portuguese is but one of the languages used and not the language which confers national "unity" - let allowance be made for the term. For this reason, there can be no skirting the matter of plurilingualism when working on the literatures of the five nations, in addition, of course, to all the diversity to be found in the cultural dimension, made even more sweeping by such linguistic polyphony. In this regard, Inocência Mata clarifies:

[I]n the case of the African literatures, in contrast to their Portuguese and Brazilian equivalents, we must not forget that this literature [in the Portuguese language] represents part - a significant part, it is true - of the literary systems of the Portuguese-speaking African countries, which systems also include productions in African, creole or autochthonous languages. (2004: 350)

This realisation is important when pondering the issue of Lusophony within the context of that part of Africa which adopted Portuguese as its official language. It is not simply the case that in some areas national languages are spoken to a larger extent than the European variant, but also that these countries produce literary works in these languages, albeit in small number. In addition, these very often confront Portuguese within the same artistic-verbal production, as attested in the poetry of Odete da Costa Semedo, a poet from Guinea-Bissau:

Irans of Bissau

from Klikir to Bissau bedju

from N'ala and from Renu

from Ntula and from Kuntum

from Ôkuri and from Bandim

[...]

The seven djorsons of Bissau

will be present 
the souls of the katanderas

will be present. (2003: 83-4)

In one of her chronicles, entitled "Mother-tongue," the Angolan poet and historian Ana Paula Tavares stresses linguistic crossover and addition in the context of her culture:

I have always taken pleasure in observing the generous alchemy of the Portuguese language, adding its voice to the Umbundu song, smiling at Kimbundu humour or incorporating words fit to make milk go off, characteristic of the Nyaneka language. The reverse is also valid and works for the entire universe of the Bantu languages and not just those spoken in the territories where today Portuguese is also spoken. (1998: 13).

At this point, it is worth mentioning the famous Brazilian "Letter to the 'Icamiabas'," one of the chapters in Mário de Andrade's Macunaíma (1928), in which the anthropophagic parody of the use of the language appears stripped of disguise. This occurs in the letter from the initial fact of Macunaíma's showing native Sao Paulans' lack of knowledge of what "icamiabas" might possibly be - another way of saying "Amazons," according to the character, in the "spurious" (1978: 59) and would-be erudite voice built up in São Paulo, the place where the letter is written. The passage below, initiated by an inside-out return to Camões, shows how the issue of the use of the Portuguese language, in the Brazilian modernist project, aims to reinforce nationhood, for which purpose it picks up anew Alencar's project, endowing it with a different meaning:

The sun had not risen five times since we left you, when [...] on a fine night in the Ides of May of the past year, we lost muiraquitã; that others spelt muraquitã, and certain learned beings, eager for arcane etymologies, spelt muyrakitan and even muraquéitã, smile not! [...] this word, so familiar to your Eustachian tubes, is almost unknown in these parts. (Andrade, 1978: 59)

The ironic tracery of the letter discloses that in São Paulo - a metonymic representation of the Brazilian cities where the colonising might solidified to a greater extent - two languages coexist: the spoken ("a barbaric and multifarious wordifying") and the written one, "very close to that of Virgil [...] a gentle tongue which, with unimpeachable gallantry, is called the language of Camões!" (ibid.: 107). The Brazilian modernist project sought to set up another locus of speech which would serve as a possible new model for the African nations, when they committed themselves to dis-assimilating from the prevailing European models. An example can be found in the poetry of Manuel Bandeira, in which the utterance of the people, the popular street cries, the songs, the new rhythm, etc., inseminate the poetic 
corpus, bestowing a certain 'Brazilianity' to the contours of this corpus, as the first stanza of "Berimbau" clearly illustrates:

The aguapés of the aguaçais In the igapós of the Japurás Move, move, move.

The saci calls: 'yes yes yes yes!'

'Awoo, awoo, awoo, awoo!' howls the iara

In the aguaçais of the igapós

Of the Japurás and of the Purus. (1977: 196)

For this very reason, some African poets such as Agostinho Neto, António Jacinto and Viriato da Cruz, for example, identified with this new rhythm in Brazilian poetry, as Bandeira expressed it, in turn creating diversified pathways and rhythmic modulations characteristic of a poetic utterance in difference. This is shown - to linger on just one of the productions of one of the poets - in "Punishment for the 'Rascal Train"” by António Jacinto, in his explicit dialogue with Bandeira's "Iron Train." Let us read the following fragments:

Coffee and bread

Coffee and bread

Coffee and bread

Holy Mother, what was that, engine driver?

[...]

Oh, Mr. Stoker

Chuck fire

Into the furnace

'Cos I need

A lotta strength

A lotta strength

A lotta strength (Bandeira, 1977: 236-37

That rascal train

goes by

goes straight by with the power it has

woo-woo woo-woo woo-woo

chuga-chuga chuga-chuga chuga-chuga

clickety-clack clickety-clack clickety-clack

the rascal train

goes by (Jacinto, 1985: 23)

On the other hand, African national literary projects use the Portuguese language itself as a way of facing up to the dominator, seeking to shatter normative rigidity and presenting 
distinct verbal solutions with which to structure the bases of an artistic production in difference. If the Greek phoné means sound, what we perceive at first is this intrinsic change at the basic sound level of the language, a procedure which is not restricted simply to this phonic level, but which increasingly goes beyond it, to reach the syntactic and morphological corpus of the language. This is what we detect, for example, when reading the novels of José Luandino Vieira, likewise Angolan. To illustrate this aesthetic procedure, I quote a passage from this author's novel João Vêncio: os seus amores [João Vêncio: Regarding his Loves] (1979), a work in which we have yet another problematic hero, like Macunaíma, and his utterance in difference as regards European norms:

I not like people - effing camundongos! The guv'ment should make hut villages far away for dese idiots live in. The city would be just shaked out beauty, houses'n'trees, nuttin' else. Nobody what come and hassled him with their catingas (1987: 81)

Outside the centre where Lusophony is set up, on its margins, to be more precise, a web of complicity is thus created, as shown, for example, by the importance which reading Jorge Amado's fiction had for the process of African authors' literary growth. This occurred precisely because Amado stages, on the one hand, the self-justifying life-styles of Bahia Blacks and, on the other, because he opts for staging an aesthetic of deprivation whereby the excluded attain their turn and voice, showing in that voice an utterance in difference:

No one had noticed Jubiabá had arrived.

The Macumba man spoke:

- But he died an ugly death...

The men lowered their heads, they knew full well they couldn't take on Jubiabá, who was a witch-doctor.

[...] He spoke in Nagô then and when Jubiabá spoke Nagô the blacks were left quaking:

- Ôjú ànun fó ti iká, li ôkú. (1983: 33-4)

The interviews which Michel Laban carried out with Angolan and Mozambican writers, among others (Laban, 1991, 1998), make it very clear how important reading Amado's work was - in addition to others, of course, such as that of the Portuguese neo-realists for the growth of readers who would become the writers of the future in the countries concerned. The Mozambican Noémia de Sousa stressed this importance when, responding to the interviewer, she explained why she had written her "Poema a Jorge Amado" [Poem to Jorge Amado]: “This is because of Jorge Amado's books: there's one book [...] I think it's São Jorge dos Ilhéus, that says: "Come my Black girl and sit on the 
jetty" [...] or could it be Jubiabá? And I was deeply affected by Jorge Amado" (Laban, 1998, 1: 307).

For all these reasons, it becomes very clear to readers of the African productions of the late 1940s onwards that these writers wished to undermine the authority of the Other who colonised them in historical and literary terms, by carrying the artistic word to their own symbolic territoriality. In so doing, they sought to overcome European authoritarian power, confronting it face to face. They turned this word, "initially an enigmatic sign of the ruling power," as stated by Polar, into a "territory to be preserved or conquered, almost as if it were a segment of the politics or of the economy of appropriations, expropriations and reappropriations, which tense and cut through colonial life in its entirety" (2000: 83). Language is one of the foundational elements of such an "economy," the result of which is a process of reallocation of the imaginary.

In "Hino à minha terra" [Hymn to my land], a sort of response to the Lusiad navigators' inability to name difference, as sung in the $16^{\text {th }}$ century epic, José Craveirinha re-names his Mozambican historical-cultural universe. His "hymn," in contrast to the Portuguese equivalent deconstructed by Lobo Antunes, is grounded on pride and a positive outlook. It opens with an epigraph that acts as a kind of proposal which throws down a riddle, so attuned to African taste:

The blood of the names

is the blood of the men

Suck it too if you can bring yourself to do it You who do not love it

And the poet goes on, after this epigraph/riddle:

Dawn breaks

On the cities of the future

And a yearning grows in the names of things

And I say Metengobalame and Macomia

and Metengobalame is the warm word

blacks made up

and nothing other Macomia

[...]

Oh the beautiful lands of my Africk country

[...] and all the names I love beautiful in the Ronga language

Macua, Swahili, Changana

Xitsua and Bitonga (1980: 21-2) 
This blood of African names, which lends lustre to so many other languages and cultures in the continent in their foundational ethno-cultural diversity, shows the cosmogonic power of the African word, always an even-further beyond-of-itself. It connects the visible and the non-visible; the living and the dead; the past and the future, as taught by Makhily Gassama, Alassame Ndaw, Honorat Aguessy, Kwame Anthony Appiah, Ruy Duarte de Carvalho, Tidjani Serpos and so many other African scholars working in different areas of knowledge.

This cosmogonic construction, which is Other, the articulator also of other symbolisations by which European-based phonics can be problematised, allows us to ponder, without any trace of essentialism - always a form of erasure rather than of reinforcement, from the viewpoint of Edward Said (1995), to which I here adhere - an Africophony, intractable, because irreducible unto itself. We need but read Wole Soyinka, Nadine Gordimer, Amadou Hampâté Bâ, Amós Tutuola, Luandino Vieira, Ungulani Ba Ka Khosa, Boaventura Cardoso, Paulina Chiziane, Abdulai Sila, Mia Couto, Pepetela, Alda Espírito Santo and so many other "written voices" to understand the meanings covered by this Africophony. In Brazil, for example, it is present in a significant number of works by writers of African descent committed to representing a locus which the literary canon always elides.

This Other-trace of permanence, outside symbolic European standards, spills itself out in a broad literary constellation. Two poetical works by the Brazilian Edimilson de Almeida Pereira and António Risério, O livro de falas ou Kalunbungu (1987) and Oriki Orixá (1996) respectively, are more than pertinent examples of the symbolic power of this constellation, whose planets are other languages, other cultures, other forms of knowledge, in sum. I quote excerpts from one of Pereira's poems:

"Kauô Kabiecile!" "Come and see the King descend upon earth!" This is Shango's salutation [...] in days of old he was the fourth monarch of the city of Oyo [...]

FESTA

From ages of old the use of lightning-bolts comes to me. [...] I suffered in the love of angels, but I crowned stone and lightning-bolt. Old words are queens and forgotten men, the deciphering of masks. (1987: 13)

I quote from one of Risério's translations in which he recreates a Yoruban oriki [praise poem], also on Shango. It begins thus:

SHANGO ORIKI 2

Shango oluasho sparking beast orobô eye 


\section{Obi cheeks}

Fire from his mouth, master of Kosso,

Fearsome orisha.

Punish whoever doesn't respect you

Crimson-clothed shango, master of the house of riches.

Mouth of fire, feline in hunting. (1996: 133)

For his part, Ruy Duarte de Carvalho pertinently clarifies the power of African symbolic matrices translated to the texts produced in the Portuguese language. Showing the entry into this language of other forms of representation which do not refer to white Western matrices, but surpass them, thereby creating a network of cultural knowledge and belonging, the Angolan author writes about an artistic procedure specific to his work, one which can be extended to several others, as is the case of the work of Edimilson Pereira and António Risério:

If it is true that, in translating and adapting into my language sources of African oral expression, I have transferred onto them the stamp of my own poetic language, it is also undoubtedly true that, in so doing, I was introducing into the Portuguese language features of an imaginary which is OTHER. (Carvalho, 1995: 75)

Ruy de Carvalho's Ondula Savana Branca [Undulate White Savanna] (1982), as is the case of Pereira's and Risério's works, is tangible proof of this effort to translate something other into the space viewed as Lusophony. This something other, though written in Portuguese, reaches far beyond a symbolic "sonority" underpinned by a Luso-European matrix, as is shown in the long poem "Peul," included in the above work, of which I quote the closing lines:

Take, at the last, the jujubas kept

in the matrix of the world.

Only those who have come this far can grasp them.

You're at the frontier of human knowledge.

From here on divine is the science at your disposal.

Foroforondou will now watch over you. (ibid., 1982: 65)

The construct of Africophony offers itself to us, through all these symbolic disseminations, as a signifier capable of covering - in the case of the continent - not one, but every language spoken there and, by extension, its polymorphic cultures which ultimately are always transculturally recovered by literatures, in a kind of artistic re-mapping, one of the most inspiring in the space of Afro-Luso-Brazilian literary and cultural studies. It is in pondering this Africophony and Brazil, as my own locus of enunciation, that I venture to raise the 
following issues, by way of a conclusion: are we truly all Lusophones, journeying through Lusophone places; thinking, loving, believing, creating, and other gerunds we might wish to add, Lusophonically? Or are we all, the ex-centrics, voyagers in a language which took the risk of dropping anchor in other, distant harbours, possessing us and always containing us as identities in difference?

To answer such musings, it is necessary to reiterate the historical-cultural fact that, through the common use of our language, a fertile space is created offering mutual possibilities for understanding, in which there is, likewise, a proliferation of many complicities and countless interwoven histories. However, for the understanding, the complicities and the histories to become more and more consolidated, it is equally necessary to construct another way of reading and viewing the web of differences, so that they can also be read and viewed without elisions or erasures laid down by any type of hegemony of a historical, symbolic and, above all, political-cultural nature. Only thus can Lusism fulfill its promise of a future, and Lusophony gain new, inspiring meanings.

Translated by Monica Varese

Revised by Teresa Tavares

\section{References}

Aguessy, Honorat (1980), "Visões e percepções tradicionais," in Alpha Sow et al., Introdução à cultura africana. Trans. Emanuel L. Godinho, Geminiano C. Franco and Ana M. Leite. Lisboa: Edições 70.

Alencar, José (1953), Sonhos d'ouro. Rio de Janeiro: José Olympio.

Amado, Jorge (1983), Jubiabá. Rio de Janeiro: Record.

Anderson, Benedict (1989), Nação e consciência nacional. Trans. Lólio L. de Oliveira. São Paulo: Ática.

Andrade, Mário de (1978), Macunaíma: O herói sem nenhum caráter. São Paulo: Martins; Belo Horizonte: Itatiaia.

Antunes, António Lobo (1999), O esplendor de Portugal. Rio de Janeiro: Rocco.

Appiah, Kwame Anthony (1997), Na casa de meu pai: A África na filosofia da cultura. Trans. Vera Ribeiro. Rio de Janeiro: Contraponto.

Aulete, Caldas (1958), Dicionário contemporâneo da língua portuguesa. 5 vols. Ed. Antenor Nascentes. Rio de Janeiro: Delta.

Bandeira, Manuel (1977), Poesia completa e prosa. Rio de Janeiro: Nova Aguilar.

Bloom, Harold (1995), O cânone ocidental: Os livros e a escola do tempo. Trans. Marcos Santarrita. Rio de Janeiro: Objetiva. 
Camões, Luís Vaz de (1972), Os Lusíadas. Rio de Janeiro: Ministério da Educação e Cultura.

Candido, Antonio (2000), "Ironia e latência," in Beatriz Berrini (ed.), A ilustre Casa de Ramires / Cem anos. São Paulo: EDUC, 17-26.

Carvalho, Ruy Duarte de (1982), Ondula, savana branca. Expressão oral africana: versões, derivações, reconversões. Lisboa: Sá da Costa.

Carvalho, Ruy Duarte de (1995), "Tradições orais, experiência poética e dados de existência," in Laura Padilha (ed.), Repensando a africanidade: ANAIS do I Encontro de Professores de Literaturas Africanas de Língua Portuguesa. Niterói: Imprensa Universitária da Universidade Federal Fluminense, 69-76.

Carvalho, Ruy Duarte de (2000), Vou lá visitar pastores: Exploração espistolar de um percurso angolano em território cuvale (1992-1997). Rio de Janeiro: Gryphus.

Craveirinha, José (1980), Xigubo. Lisboa: Edições 70.

Ferreira, Aurélio Buarque de Holanda (1988), Dicionário Aurélio Básico da Língua Portuguesa. Rio de Janeiro: Nova Fronteira.

Ferreira, Aurélio Buarque de Holanda (1999), Dicionário Aurélio Eletrônico. Século XXI. Rio de Janeiro: Lexicon Informática/Nova Fronteira (CD-ROM).

Garrett, Almeida (1946), Viagens na minha terra. Porto: Livraria Tavares Martins.

Gassama, Makhily (1978), Kuma: Interrogation sur la littérature nègre de langue française. Dakar-Abidjan: Les Nouvelles Éditions Africaines.

Gil, Fernando; Macedo, Helder (1998), Viagens do olhar. Porto: Campo das Letras.

Hall, Stuart (2003), A identidade cultural na pós-modernidade. Trans. Tomás T. da Silva and Guacira L. Louro. Rio de Janeiro: DP\&A.

Houaiss, Antônio (2001), Dicionário HOUAISS da língua portuguesa. Rio de Janeiro: Objetiva.

Jacinto, António (1985), Poemas. Luanda: Instituto Nacional do Livro e do Disco.

Laban, Michel (1991), ANGOLA: Encontro com escritores. 2 vols. Porto: Fundação Eng. António de Almeida.

Laban, Michel (1998), MOÇAMBIQUE: Encontro com escritores. 3 vols. Porto: Fundação Eng. António de Almeida.

Lopes, Fernão (1997), A crônica de Dom João. In As Crônicas de Fernão Lopes: Selecionadas e transpostas em português moderno. Ed. António José Saraiva. Lisboa: Gradiva, 145-354.

Lourenço, Eduardo (1988), O labirinto da saudade: Psicanálise mítica do destino português. Lisboa: Publicações Dom Quixote.

Lourenço, Eduardo (2001), A nau de Ícaro e Imagem e miragem da lusofonia. São Paulo: Companhia das Letras.

Macedo, Helder (1991), Partes de África. Lisboa: Presença.

Macedo, Helder (1998), Pedro e Paula. Lisboa: Presença.

Madeira, Ana Isabel (2003), Sons e silêncios da lusofonia: Uma reflexão sobre os espaços-tempos da língua portuguesa. Lisboa: EDUCA. 
Margarido, Alfredo (2000), A lusofonia e os lusófonos: Novos mitos portugueses. Lisboa: Edições Universitárias Lusófonas.

Mata, Inocência (2004), "A invenção do espaço lusófono," in HOMO VIATOR - Estudos em homenagem a Fernando Cristóvão. Lisboa: Colibri, 345-355.

Melo, João de (1984), Autópsia de um mar de ruínas. Lisboa: Assírio e Alvim.

Mignolo, Walter (2003), Histórias locais / Projetos globais: Colonialidade, saberes subalternos e pensamento liminar. Trans. Solange Ribeiro de Oliveira. Belo Horizonte: Editora da Universidade Federal de Minas Gerais.

Ndaw, Alassane (1983), La pensée africaine: Recherches sur les fondements de la pensée négro-africaine. Dakar: Les Nouvelles Éditions Africaines.

Nascentes, Antenor (1972), Dicionário ilustrado da língua portuguesa. 6 vols. Rio de Janeiro: Bloch / Academia Brasileira de Letras.

Pereira, Edimilson de Almeida (1987), O livro de falas ou kalunbungo: Achados da emoção inicial. Juiz de Fora: Edição do Autor.

Pessoa, Fernando (1974), Obra poética. Rio de Janeiro: Aguilar.

Polar, Antonio Cornejo (2000), O condor voa: Literatura e cultura latino-americanas. Ed. Mario J. Valdés. Trans. Ilka V. de Carvalho. Belo Horizonte: Editora da Universidade Federal de Minas Gerais.

Queiroz, Eça de (1947a), A ilustre Casa de Ramires. Porto: Lello \& Irmãos.

Queiroz, Eça de (1947b), Minas de Salomão. Porto: Lello \& Irmãos.

Ribeiro, Margarida Calafate (2004), Uma história de regressos: Império, guerra colonial e pós-imperialismo. Porto: Afrontamento.

Risério, Antônio (1996), Oriki Orixá. São Paulo: Perspectivas.

Said, Edward (1995), Cultura e imperialismo Trans. Denise Bottman. São Paulo: Companhia das Letras.

Santos, Boaventura de Sousa (2001), "Entre Próspero e Caliban: Colonialismo, pós-colonialismo e inter-identidade," in Maria Irene Ramalho; António Sousa Ribeiro (eds.), Entre ser e estar: Raízes, percursos e discursos da identidade. Porto: Afrontamento, 13-85.

Santos, Boaventura de Sousa; Nunes, Arriscado (2003), "Introdução: Para ampliar o cânone do reconhecimento e da igualdade," in B. de Sousa Santos (ed.), Reconhecer para libertar: Os caminhos do cosmopolitismo multicultural. Rio de Janeiro: Civilização Brasileira, 25-68.

Saramago, José (1982), Levantado do chão. São Paulo: DIFEL.

Saramago, José (1983), Memorial do convento. São Paulo: DIFEL

Saramago, José (1984), O ano da morte de Ricardo Reis. Lisboa: Caminho.

Saramago, José (1986), A jangada de pedra. Lisboa: Caminho.

Saramago, José (1998), Que farei com este livro?. São Paulo: Companhia das Letras.

Seixo, Maria Alzira (2002), Os romances de António Lobo Antunes. Lisboa: Dom Quixote. 
Semedo, Odete Costa (2003), No fundo do canto. Viana do Castelo: Câmara Municipal.

Silva, Alberto da Costa e (2000), "Gonçalo Mendes Ramires, prazeiro na Zambézia", in Beatriz Berrini (ed.), A ilustre Casa de Ramires / Cem anos. São Paulo: EDUC, 9-15.

Serpos, Noureini Tidjani (1987), Aspects de la critique africaine. Paris: SILEX.

Tavares, Ana Paula (1998), O sangue da buganvília: Crônicas. Praia-Mindelo: Centro Cultural Português.

Todorov, Tzvetan (1989), Nous et les autres: La refléxion française sur la diversité humaine. Paris: Seuil.

Vieira, José Luandino (1987), João Vêncio: Os seus amores. Lisboa: Edições 70.

Zurara, Gomes Eanes (1992), Crónica da Tomada de Ceuta. Ed. by Reis Brasil. Mem Martins: Publicações Europa-América. 